\title{
Translation initiation factor modifications and the regulation of protein synthesis in apoptotic cells
}

\author{
MJ Clemens ${ }^{*, 1}$, M Bushell ${ }^{1}$, IW Jeffrey ${ }^{1}$, VM Pain ${ }^{2}$ and \\ SJ Morley ${ }^{2}$ \\ 1 Department of Biochemistry and Immunology, Cellular and Molecular \\ Sciences Group, St George's Hospital Medical School, Cranmer Terrace, \\ London SW17 ORE, UK \\ 2 Biochemistry Group, School of Biological Sciences, University of Sussex, \\ Brighton BN1 9QG, UK \\ * Corresponding author: MJ Clemens, Department of Biochemistry and \\ Immunology, Cellular and Molecular Sciences Group, St George's Hospital \\ Medical School, Cranmer Terrace, London SW17 ORE, UK. Tel: +44 208725 \\ 5770; Fax: +44 208725 2992; E-mail: M.Clemens@sghms.ac.uk
}

Received 6.12.99; revised 25.1.00; accepted 20.3.00

Edited by M Piacentini

\begin{abstract}
The rate of protein synthesis is rapidly down-regulated in mammalian cells following the induction of apoptosis. Inhibition occurs at the level of polypeptide chain initiation and is accompanied by the phosphorylation of the $\alpha$ subunit of initiation factor elF2 and the caspase-dependent cleavage of initiation factors elF4G, elF4B, elF2 $\alpha$ and the p35 subunit of elF3. Proteolytic cleavage of these proteins yields characteristic products which may exert regulatory effects on the translational machinery. Inhibition of caspase activity protects protein synthesis from long-term inhibition in cells treated with some, but not all, inducers of apoptosis. This review describes the initiation factor modifications and the possible signalling pathways by which translation may be regulated during apoptosis. We discuss the significance of the initiation factor cleavages and other changes for protein synthesis, and the implications of these events for our understanding of the cellular changes associated with apoptosis. Cell Death and Differentiation (2000) 7, 603-615.
\end{abstract}

Keywords: apoptosis; protein synthesis; signal transduction; translational control

\footnotetext{
Abbreviations: $4 \mathrm{E}-\mathrm{BP}$, eukaryotic initiation factor $4 \mathrm{E}$ binding protein; Apaf-1, apoptotic protease-activating factor 1; BOC.D.FMK, t-butoxycarbonyl-Asp(OMe).fluoromethylketone; DISC, death-inducing signalling complex; dsRNA, doublestranded RNA; elFs, eukaryotic initiation factors; FADD, Fasassociated death domain; IAP, inhibitor of apoptosis protein; MAPK, mitogen-activated protein kinase; $\mathrm{PABP}$, poly(A) binding protein; PARP, poly(ADP-ribose) polymerase; z-VAD.FMK, Z-Val-AlaAsp.fluoromethylketone
}

\section{Introduction}

Apoptosis is now recognized to be an important physiological process by which cell and tissue growth, differentiation and programmes of development are regulated. The molecular mechanisms of apoptosis have been the subject of intense research in recent years (for reviews see ${ }^{1-5}$ ). Cell death is induced following the stimulation of specific cell surface receptors such as the CD95 (Apo-1/Fas) antigen or the tumour necrosis factor- $\alpha(\mathrm{TNF} \alpha)$ receptor- 1 (TNFR-1). ${ }^{6}$ It can also result from intracellular events such as DNA damage or from a lack of specific growth factors. The relative importance of these different influences varies between cell types. The apoptotic process can be divided into a commitment phase and an execution phase. As described later in this review, the former phase involves the formation of multi-protein complexes which are either associated with specific cell membrane receptors (the death-inducing signalling complex $(\mathrm{DISC}))^{7,8}$ or are assembled in the cytoplasm ('aposomes' and 'apoptosomes') ${ }^{9}$. These complexes comprise various adapter proteins together with one or more cysteine proteases (caspases). ${ }^{10,11}$ In each case a specific caspase (usually caspase-8 or -9) is activated and this enzyme then catalyses the activation of further caspase cascades by limited proteolysis. ${ }^{12-14}$ During the execution phase the downstream caspases than target a variety of other cellular proteins for cleavage. As a consequence of such cleavages several further events occur, including the activation of DNA endonuclease activity, changes in cell permeability, cytoplasmic vacuolation and ultimately loss of cell viability.

In some systems cell death induced by CD95 or TNFR-1 activation can be completely blocked by caspase inhibitors (reviewed in reference ${ }^{15}$ ). However in other situations caspase inhibitors block only part of the overall apoptotic programme (e.g. following activation of the c-myc oncogene, treatment of cells with the DNA damaging agent etoposide, or induction of activity of the pro-apoptotic gene, $\left.B a k^{16}\right)$, and it is likely that there are additional pathways involved (upstream of or parallel with caspase function). ${ }^{17,18}$ Activation of such pathways can lead to loss of cellular growth potential and result in some of the morphological changes characteristic of apoptosis even in the absence of caspase activity. ${ }^{16,19-21}$

Until recently relatively little attention has been paid to the changes in protein synthesis, in terms of either overall translational activity or alterations in mRNA selection, that accompany the commitment and execution phases of apoptosis. However, recent findings have begun to shed some light on this topic and provide insights into the possible mechanisms involved. This review describes these developments and indicates the likely physiological significance of the data for our understanding of translational control during apoptosis. 


\section{Mechanism and regulation of initiation of protein synthesis}

The initiation of protein synthesis involves complex interactions between a large number of protein initiation factors and RNA molecules. ${ }^{22,23}$ The process requires specific proteinprotein binding between individual factors as well as between these factors and the ribosome (summarized in Figure 1). An early event in the initiation pathway is the association of eukaryotic initiation factor (eIF) 2 with the initiating methionyltRNA (Met-tRNA ${ }_{f}$ ) and a molecule of GTP. ${ }^{24}$ This ternary complex can then bind to the smaller (40S) ribosomal subunit. Another factor, elF4E, binds directly to mRNA via the 5 methylated guanosine cap structure. elF4E also has the ability to bind to the factor elF4G. The latter is a large polypeptide which has binding sites for yet more protein synthesis initiation factors. ${ }^{25,26}$ One of these, the multi-subunit elF3 protein, is itself able to bind to both ribosomes and

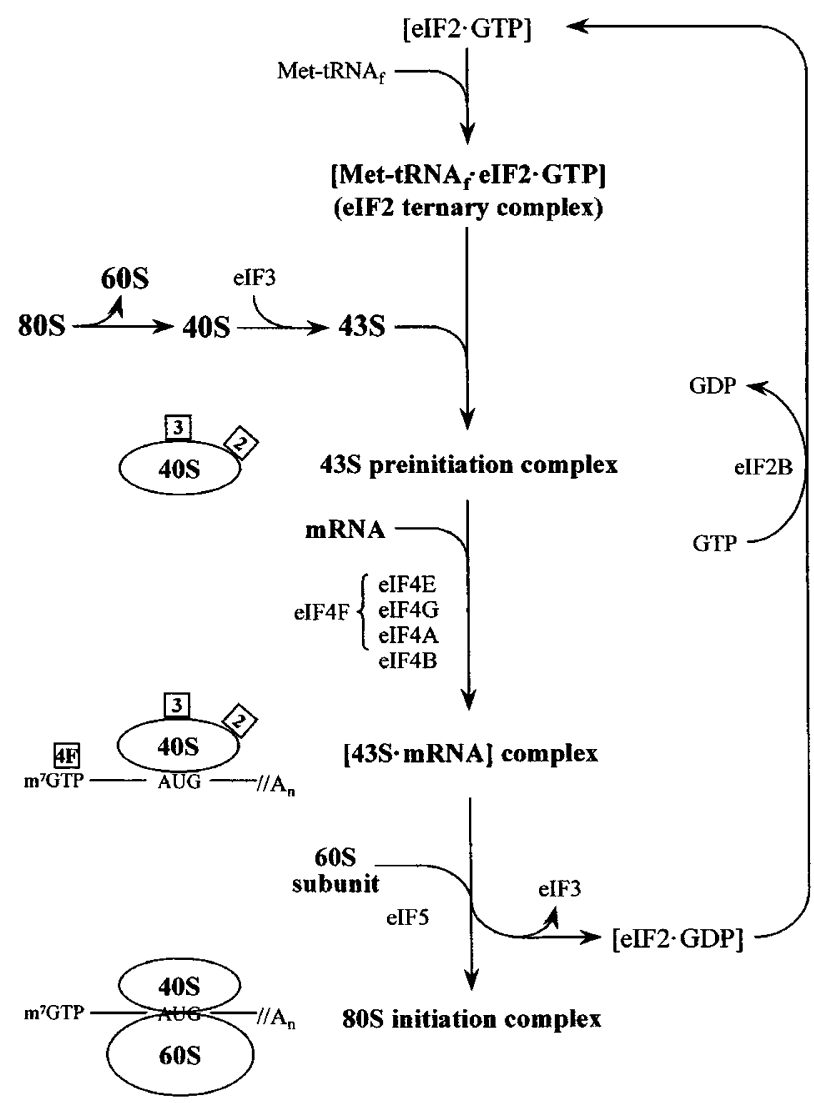

Figure 1 Summary of the initiation of protein synthesis. A complex of the initiation factor elF2 with GTP binds the initiator Met-tRNA $A_{f}$ to form a [MettRNA $\left._{\mathrm{f}} \cdot \mathrm{elF2} \cdot \mathrm{GTP}\right]$ ternary complex. This then associates with a $40 \mathrm{~S}$ ribosomal subunit carrying elF3 (and other factors - not shown) to produce the 43S preinitiation complex. mRNA binding to this complex involves the participation of the trimeric elF4F complex, comprising the cap-binding protein elF4E, the scaffold protein elF4G and the RNA helicase elF4A, together with the helicase-stimulatory factor elF4B. Joining of the $60 \mathrm{~S}$ subunit and hydrolysis of the GTP, catalysed by elF5, leads to the formation of the $80 \mathrm{~S}$ initiation complex which can commence protein synthesis. The GDP formed as a result of GTP hydrolysis remains associated with the elF2 and is later exchanged for another molecule of GTP by elF2B. Modified from Figure 1 of reference ${ }^{22}$
mRNA, as well as enhancing the ability of the elF2 ternary complex to bind to $40 \mathrm{~S}$ subunits.

From the above it will be apparent that elF4G plays a crucial role by acting as a bridge between components such as the cap-binding protein elF4E and the elF3 complex, thus allowing the mRNA molecule to associate with the $40 S$ ribosomal subunit (reviewed in ${ }^{23,25,27}$ ). In mammalian cells elF4G is a large polypeptide, originally thought to have a mass of $154 \mathrm{kDa},{ }^{28}$ but now known to be larger than this. ${ }^{29,30}$ This protein exists partly in the form of a trimeric complex with elF4E and the ATP-dependent RNA helicase elF4A, forming the initiation factor elF4F. ${ }^{31} A$ second form of elF4G (elF4GII) has also been described. ${ }^{32}$ elF4G has domains for the binding of elF4E and elF3 in its $\mathrm{N}$-terminal and central regions respectively, as well as binding sites for elF4A, ${ }^{33,34}$ the $\operatorname{poly}(A)$ binding protein $(\mathrm{PABP})^{29,35-37}$ and the elF4E kinase $M n k 1^{38}$ (see Figure 3 for the locations of these domains).

The association of elF4G with elF4E strongly enhances the binding of the latter to $5^{\prime}$ mRNA cap structures. ${ }^{39}$ However this association is inhibited by a family of $4 \mathrm{E}$ binding proteins (4E-BPs) which can compete with elF4G for binding to elF4E. ${ }^{40-43}$ The extent of complex formation between the best studied of these proteins, $4 \mathrm{E}-\mathrm{BP} 1,{ }^{44}$ and elF4E is regulated by the phosphorylation of $4 \mathrm{E}-\mathrm{PB} 1$. $^{4-48}$

To enable translation to begin at the correct site on an mRNA the [40S subunit.Met-tRNA f $_{\mathrm{f}}$ complex must locate the initiating AUG codon. This usually requires the ribosome to scan along the mRNA in a $3^{\prime}$ direction from the cap site, a process which often requires the transient 'melting' of secondary structure in the mRNA. ${ }^{22}$ This function needs the RNA helicase activity of elF4A, which is stimulated by another accessory factor, elF4B. In some cases, the need for cap recognition and/or scanning can be by-passed by internal initiation, in which the [40S subunit-Met-tRNA $A_{f}$ complex binds directly to an internal ribosome entry site (IRES). This is most commonly seen in the case of picornavirus mRNAs but is also the case for some cellular mRNAs. ${ }^{49-53}$ Certain mRNAs, such as c-myc or c-sis, may be capable of being translated by either mechanism, depending on the conditions in the cell ${ }^{54,55}$ (reviewed in reference ${ }^{56}$ ). Interestingly some of these mRNAs also contain alternative start sites for protein synthesis and can encode functionally distinct products. ${ }^{57,58}$

Following the location of the AUG initiation codon on the mRNA two additional events must occur. The GTP associated with the elF2 is hydrolysed to GDP, in parallel with the dissociation of the previously bound initiation factors from the ribosome. GTP hydrolysis requires the involvement of the factor elF5. The GDP that is generated remains associated with the elF2 and must be exchanged for another molecule of GTP in a process catalysed by the guanine nucleotide exchange factor elF2B. ${ }^{24}$ The second event is the binding of the larger (60S) ribosomal subunit to the initiation complex to form the complete $80 \mathrm{~S}$ initiation complex.

Dramatic changes occur in the integrity of elF4G after infection of cells with picornaviruses such as polio or footand-mouth-disease virus (reviewed in ${ }^{25}$ ). Within a few 
hours both elF4GI and elF4GIl are cleaved by viral and/or cellular proteases at a region between the elF4E and elF3 binding sites, ${ }^{59}$ with the effect on elF4GI preceding that on elF4GII. ${ }^{60,61}$ These cleavages destroy the bridging function of elF4G in protein synthesis and lead to the inhibition of cap-dependent initiation. ${ }^{62}$ Recent work suggests that the kinetics of cleavage of elF4GIl correlate better than those of elF4Gl cleavage with the time of down-regulation of protein synthesis in picornavirus-infected cells. ${ }^{60,61}$ Several studies indicate that the remaining C-terminal fragment of elF4G can still support initiation involving ribosome binding to internal sites on mRNAs (which is therefore capindependent). ${ }^{63,64}$ As a result picornavirus RNA-directed protein synthesis, which occurs by internal initiation, is favoured. It is not yet clear whether a similar mechanism is used to inhibit cap-dependent protein synthesis in uninfected cells, in which some cellular mRNAs can also be translated by an internal initiation mechanism, although there have been reports of the cleavage of elF4G under situations where protein synthesis is down-regulated. ${ }^{65,66}$

\section{Changes in translational activity during apoptosis}

Induction of apoptosis has been shown to be associated with a rapid and substantial inhibition of protein synthesis in several cell types. ${ }^{67-71}$ In our own work we have observed decreases of about $60-70 \%$ within a few hours of induction of apoptosis by treatment of Jurkat $\mathrm{T}$ cells with anti-CD95 antibody or of MCF-7 breast cancer cells with TNF $\alpha$. The mechanisms involved probably depend on the nature of the apoptotic inducer, since in Jurkat cells the down-regulation of translation following CD95 stimulation, but not that caused by the DNA damaging agent etoposide, can be completely abrogated by the broad spectrum caspase inhibitor zVAD.FMK. ${ }^{69}$ Similarly, in MCF-7 cells the effects of TNF $\alpha$ are prevented by z-VAD.FMK or another caspase inhibitor, BOC.D.FMK (IW Jeffrey, VJ Tilleray and MJ Clemens, unpublished data). Caspase-3 also partially inhibits protein synthesis in a cell-free system and this effect too is blocked by z-VAD.FMK (M Bushell, W Wood and SJ Morley, unpublished data). Thus the caspases play an important role in the downregulation of protein synthesis during apoptosis, although there may also be caspase-independent components in the pathway(s) by which agents such as etoposide exert their effects on translation.

The inhibition of protein synthesis in apoptosing cells is associated with a substantial decrease in the proportion of ribosomes in polysomes, ${ }^{69,72}$ strongly suggesting that there is a block at the stage of polypeptide chain initiation. However we cannot rule out the possibility that other changes, such as altered rates of polypeptide elongation or decreased stability of ribosomes or mRNA (eg due to caspase-mediated activation of nucleases - see accompanying review by Degen et al. $^{73}$ ), also contribute to the effect.

\section{Polypeptide chain initiation factors as substrates for caspase-mediated cleavage}

Recent studies from our laboratories and others have demonstrated that a limited number of initiation factors are targets for specific degradation by caspase-mediated mechanisms in a variety of cell types and in response to several inducers of apoptosis. In an investigation of the effects of deprivation of serum growth factors on protein synthesis in the human BJAB B cell lymphoma line we observed a very marked and progressive disappearance of elF4G. ${ }^{68}$ In contrast, under the same conditions there were no major decreases in the levels of several other initiation factors, including elF4E and elF4A. BJAB cells undergo apoptosis when placed in low serum concentrations, as indicated by the appearance of a specific cleavage product of the classical caspase substrate poly(ADP-ribose) polymerase (PARP). Further work showed that another physiological means of inducing apoptosis, viz. stimulation of the CD95 antigen, also led to pronounced cleavage of elF4G in both BJAB and Jurkat cells. $^{68,69}$ This cleavage was prevented by treating the cells with z-VAD.FMK. Similar results were seen using these and other cell types following induction of apoptosis with cycloheximide, etoposide, $\mathrm{TNF} \alpha$ or the protein kinase inhibitor staurosporine. ${ }^{68-70,74}$ In each case, elF4E remained quite stable under conditions where elF4G disappeared with rapid kinetics. The elF4G normally found in association with elF4E in the elF4F complex was vulnerable to cleavage. In all cases preincubation of cells with caspase inhibitors protected elF4G from degradation.

The disappearance of intact elF4GI is accompanied by the appearance of discrete breakdown products including a major fragment, originally designated $p 76^{68}$ but which has been more recently termed M-FAG (middle fragment of apoptotic cleavage of elF4G) ${ }^{75}$ with a mass of ca. $72 \mathrm{kDa}$ (Figure 2). The breakdown products of elF4GI are reasonably stable in our experience, although others have suggested that only a small fraction of the protein generates discrete fragments. ${ }^{76}$ The appearance of $\mathrm{M}$ FAG and the other products is prevented by caspase inhibitors. $^{68,75}$ Strikingly, in MCF-7 cells, which are deficient in caspase-3, elF4GI is not cleaved to give rise to M-FAG during apoptosis. ${ }^{74}$ The M-FAG fragment that appears in cells undergoing apoptosis is not the same as either of the fragments that appear as a result of specific proteolytic cleavage of elF4GI in picornavirus-infected cells. Figure 3 shows a map of the locations of the caspase-3 cleavage sites on the elF4GI sequence, determined by $\mathrm{N}$-terminal microsequencing, and contrasts the characteristics of the cleavage products with those of the fragments generated by picornavirus-encoded proteases. An important difference between the two patterns of cleavage is that the viral enzymes cut elF4GI at only one site but caspase- 3 makes two cleavages. As a consequence, after caspase-3 cleavage the elF4E binding domain remains attached to the central domain of elF4GI in the M-FAG fragment, whereas the fragment $C_{t}$ generated by the viral proteases has lost the elF4E binding site (Figure 3). M-FAG can also be produced by direct caspase-3 cleavage of elF4GI in vitro, both in the reticulocyte lysate system and using recombinant proteins. This finding, together with the data from the MCF-7 cell studies, demonstrates that caspase-3 is both necessary and sufficient for elF4GI cleavage. In this respect elF4GI resembles the cytoskeletal protein $\alpha$-fodrin in being one of 
the few proteins which are apparently not substrates for other caspases in the cell.

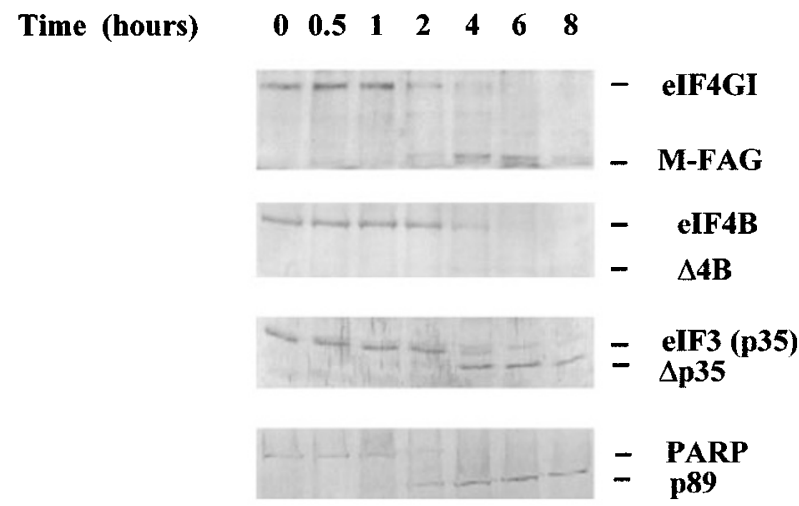

Figure 2 Initiation factor cleavages during apoptosis. Apoptosis was induced in human BJAB cells (in this case by treatment with cycloheximide) and cell extracts were prepared at the times indicated. Proteins were separated by SDS gel electrophoresis and subjected to immunoblotting using antisera directed against the $\mathrm{C}$-terminal third of elF4GI (amino acids 1079-1560 in the revised numbering system of Imataka et al. ${ }^{29}$ ), elF4B, elF3 and the apoptotic marker protein PARP. The full-sized protein and a specific cleavage product generated by caspase-dependent proteolysis are indicated for each panel. MFAG is the middle fragment of elF4GI (see Figure 3). Note that $\Delta 4 \mathrm{~B}$ (the cleavage product of elF4B) is only weakly recognised by the antiserum to this factor
Further investigations into the integrity of other initiation factors in cells undergoing apoptosis have now shown that, in addition to elF4GI, there is selective cleavage of elF4B and the smallest subunit of elF3 (p35). ${ }^{77}$ These cleavages occur in response to serum deprivation or treatment of cells with anti-CD95, etoposide or cycloheximide. In contrast, none of the other 10 subunits of elF3 are degraded under the same conditions. As in the case of elF4GI caspase-3 is both necessary and sufficient for elF3 (p35) cleavage; however elF4B is also cleaved during apoptosis in MCF-7 cells (IW Jeffrey and M Bushell, unpublished data), suggesting that other caspases may also target this protein for degradation. We have also found that small proportions of the $\alpha$ subunit of elF2 and the elF4E-binding protein 4E-BP1 are cleaved to give rise to discrete fragments. ${ }^{77}$ Such changes have also been described by other laboratories ${ }^{78}$ (A Tee and CG Proud, personal communication).

In BJAB cells the cleavages of elF4B and elF3(p35) occur with delayed kinetics relative to that seen for elF4GI. ${ }^{77}$ Purified recombinant caspase-3 is able to degrade elF4B and elF3(p35) in vitro, producing fragments of the same sizes as those seen in intact cells, and the cleavage sites in these proteins have now been identified. Cleavage of elF4B occurs between amino acids 45 and 46, after the sequence DETD, and cleavage of elF3(p35) occurs on the C-terminal side of amino acids 242 (after the sequence DLAD) and/or 256 (after the sequence DYED). ${ }^{77}$

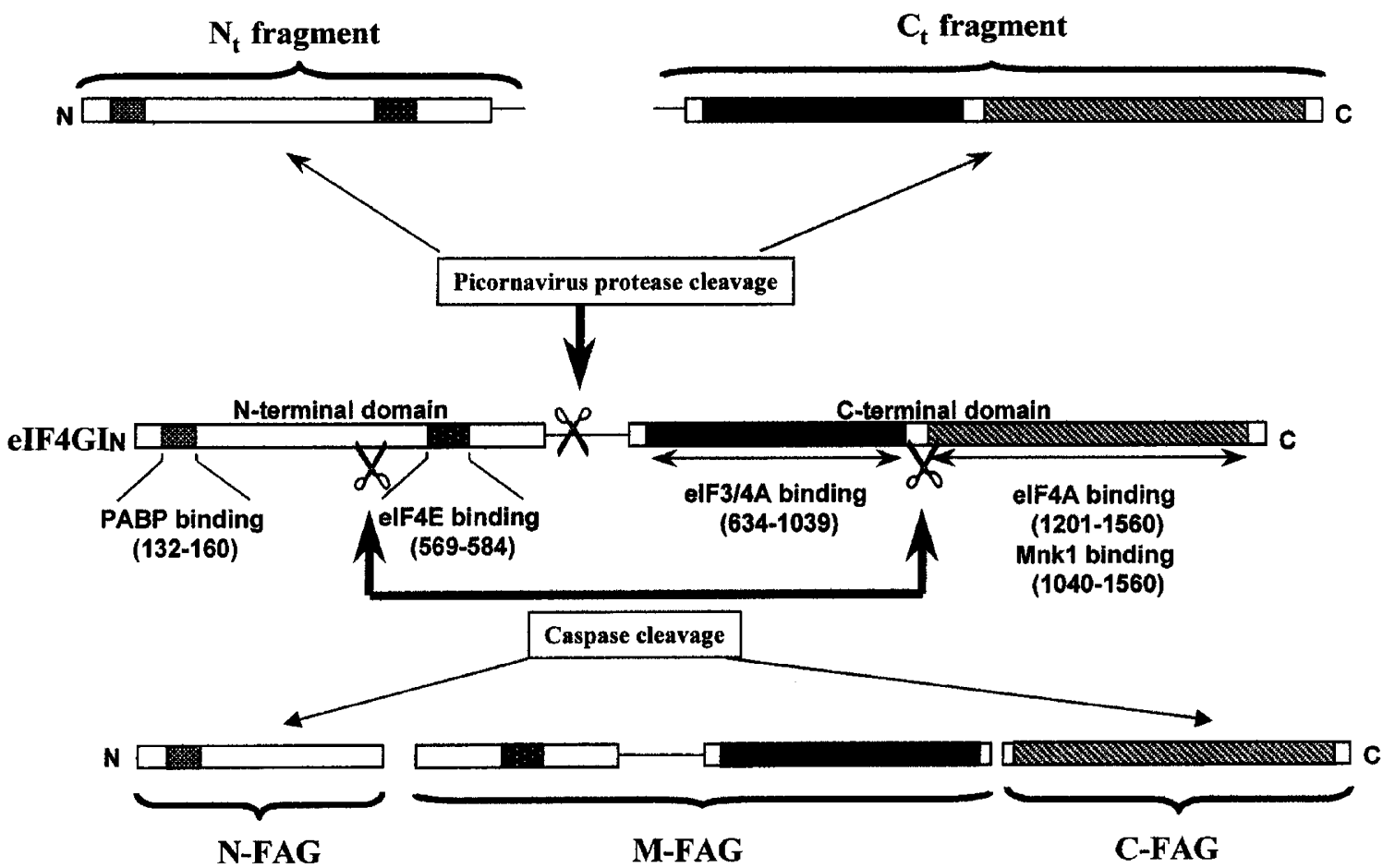

Figure 3 Caspase cleavage sites in elF4GI and characteristics of the fragments generated. The domain structure of elF4GI is shown in the centre of the Figure, with the cleavage products generated by picornavirus protease-mediated cleavage and caspase-mediated cleavage indicated above and below respectively. The amino acid numbering system of Imataka et al. ${ }^{29}$ is used. Note that the $L$ protease of foot-and-mouth-disease virus and the $2 A$ protease of poliovirus cleave after residues 634 and 641 respectively, each producing two fragments of elF4GI, $N_{t}$ and $C_{t}$. This separates the elF4E binding domain from the elF3 and elF4A binding domains. In contrast caspase-3 cleaves at two sites in elF4GI (after residues 492 and 1136) to produce three fragments, N-FAG, M-FAG and C-FAG. The M-FAG fragment retains the ability to bind elF4E, elF3 and elF4A but loses the binding sites for PABP and the elF4E protein kinase Mnk1 
We have also found that the second form of elF4G recently described, elF4GII, is cleaved during apoptosis. This happens with the same kinetics as elF4GI cleavage and in this respect the behaviour of the two forms of elF4G is different from the situation in poliovirus infection where elF4GII is fragmented more slowly than elF4GI. ${ }^{60,61}$

\section{Further aspects of translational regulation in apoptotic cells}

Although the induction of apoptosis by stimulation of the CD95 or TNF $\alpha$ receptors inhibits overall protein synthesis in a way which can be completely prevented by treating cells with zVAD.FMK, these data do not necessarily prove that elF4G, elF4B or elF3(p35) are the critical targets responsible for down-regulation of translation. At early times during CD95induced apoptosis in Jurkat cells or TNF $\alpha$-induced apoptosis in MCF-7 cells we have also observed increased elF2 $\alpha$ kinase activity and a transient increase in the phosphorylation of elF2 $\alpha$. However the increase in elF2 $\alpha$ phosphorylation is not prevented by zVAD.FMK and it is not yet clear whether it is part of the apoptotic response or is a separate 'stress' response of cells to anti-CD95 or TNF $\alpha$ stimulation. Phosphorylation of elF $2 \alpha$ is followed by the caspasedependent cleavage of the factor at later times (S Morley, M Bushell and IW Jeffrey, unpublished data). Comparison of the behaviour of wild-type Jurkat cells and cells deficient in caspase-8 activity (which are therefore resistant to anti-CD95induced apoptosis) has demonstrated that in both cases the timing of the transient increase in elF $2 \alpha$ phosphorylation coincides with the onset of the inhibition of translation and occurs prior to detectable cleavage of elF4GI. At slightly later times, when activation of the CD95 receptor results in the caspase-8-dependent cleavage of elF4GI in wild-type Jurkat cells, dephosphorylation and degradation of the ribosomal protein $\mathrm{S} 6$ kinase $\mathrm{p} 70^{\mathrm{S} 6 \mathrm{~K}}$ have also been observed (S Morley, unpublished data).
Changes in the state of phosphorylation of elF4E also occur during apoptosis. Although the level of total elF4E in the cytoplasm does not change as apoptosis proceeds, a decline in the extent of phosphorylation of the factor is evident in both BJAB cells ${ }^{75}$ and Jurkat cells (S Morley and $\mathrm{L}$ McKendrick, unpublished data). A similar phenomenon has been reported upon stimulation of an apoptotic response in immature thymocytes with anti-CD3 plus antiCD4 antibodies. ${ }^{79}$ We have also observed a substantial increase in the association of the binding protein 4E-BP1 with elF4E at later times after induction of apoptosis in BJAB cells ${ }^{77}$ and Jurkat cells (S Morley, unpublished data), whereas the level of total 4E-BP1 in the cytoplasm hardly changes over several hours after activation of the apoptotic response.

Collectively these data therefore suggest that several proteins which impinge upon the control of protein synthesis are direct or indirect targets for caspasemediated regulation in vivo (summarized in Table 1). However, it is not yet possible to rank the relative importance of these various events in mediating the inhibition of translation that occurs during apoptosis.

\section{Signal transduction mechanisms in apoptosis and their relevance to control of translation}

Over recent years, a large amount of effort has gone into understanding how death signals are propagated in cells to promote apoptosis. The cytoplasmic compartment contains the core apoptotic machinery in a latent or sequestered form. It is now apparent that activation of these proteins requires specific protein sequence domains which facilitate translocation to and from the plasma membrane, mitochondria and nucleus. However, relatively little is yet known about the signalling mechanisms employed by cells to bring about the inhibition of protein synthesis which is associated with the induction of apoptosis, or the effects that apoptotic signalling

Table 1 Summary of initiation factor changes associated with apoptosis

\begin{tabular}{|c|c|c|}
\hline Initiation factor & Modification & Consequences \\
\hline elF4GI and elF4GII & $\begin{array}{l}\text { Caspase-mediated cleavages after amino acids } 492 \\
\text { and } 1136 \text { in elF4GI }\end{array}$ & $\begin{array}{l}\text { Generation of discrete cleavage fragments; loss of } \\
\text { 'bridging' function of elF4G; possible inhibition of } \\
\text { mRNA circularization; potential changes in mRNA } \\
\text { recruitment }\end{array}$ \\
\hline elF4B & Caspase-mediated cleavage after amino acid 45 & Generation of N-terminally truncated cleavage product \\
\hline elF3 (p35 subunit) & $\begin{array}{l}\text { Caspase-mediated cleavages after amino acids } 242 \\
\text { and/or } 256\end{array}$ & $\begin{array}{l}\text { Generation of C-terminally truncated cleavage pro- } \\
\text { duct(s) }\end{array}$ \\
\hline elF2 $\alpha$ & Caspase-mediated cleavage after amino acid 300 & $\begin{array}{l}\text { Generation of C-terminally truncated cleavage product; } \\
\text { protection of protein synthesis from inhibition by } \\
\text { phosphorylation of elF } 2 \alpha\end{array}$ \\
\hline elF2 $\alpha$ & Phosphorylation at Ser ${ }^{51}$ & $\begin{array}{l}\text { Inhibition of guanine nucleotide exchange on elF2 } \\
\text { (catalysed by elF2B), with consequent impairment of } \\
\text { elF2 function }\end{array}$ \\
\hline 4E-BP1 & Caspase-mediated cleavage (site unknown) & $\begin{array}{l}\text { Generation of truncated cleavage product; functional } \\
\text { consequences not known }\end{array}$ \\
\hline 4E-BP1 & Possible dephosphorylation & $\begin{array}{l}\text { Increased binding to (and potential sequestration of) } \\
\text { el4FE }\end{array}$ \\
\hline elF4E & Dephosphorylation & Possible inhibition of cap-binding activity \\
\hline
\end{tabular}

This table summarizes the various modifications of polypeptide chain initiation factors observed in apoptosing cells 
pathways may have on the phosphorylation and activity of translation initiation factors. The current information concerning the pathways involved is summarized in Figure 4.

Transmembrane receptors of the tumour necrosis factor (TNF) receptor family, such as CD95, can promote rapid programmed cell death upon interaction with their cognate ligands or agonistic antibodies. ${ }^{80,81}$ The essential signalling events in this process have been the subject of numerous reviews. ${ }^{10,82-85}$ The activated receptors recruit key signalling proteins to form the DISC complex. ${ }^{8,84,85} \mathrm{An}$ adapter protein, Fas-associated death domain protein (FADD or MORT-1), ${ }^{86,87}$ is translocated and recruited via its C-terminal 'death domain' and this in turn recruits procaspase-8 (FLICE/MACH $\alpha 1 /$ Mch5) to the DISC in association with the Flice-associated huge protein (FLASH). 85,88-91 Following the dimerisation and autocatalytic cleavage of pro-caspase- 8 at internal aspartate residues

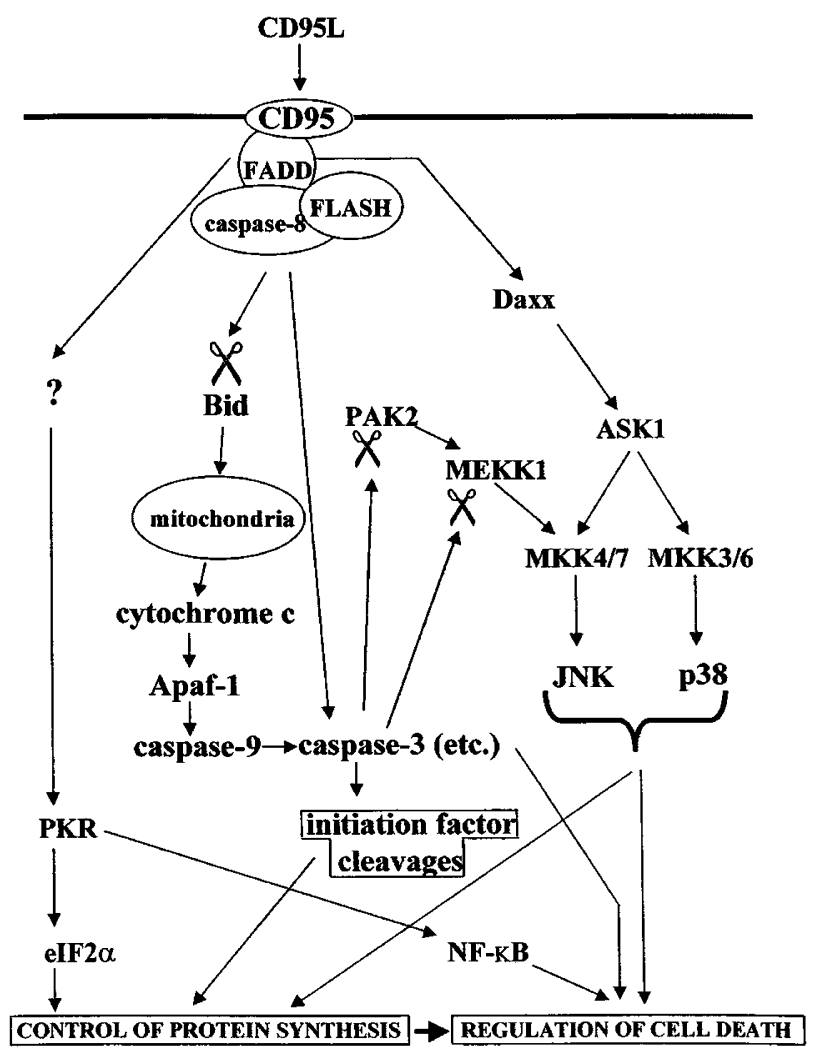

Figure 4 Signalling pathways by which protein synthesis may be regulated during apoptosis. When cells are induced to undergo apoptosis executioner caspases (e.g. caspase-3) become activated by mechanisms involving death receptors such as the CD95 (Fas) receptor, and/or by a pathway involving mitochondrial-derived proteins such as cytochromec and Apaf-1. The executioner caspases cleave many protein substrates including the protein synthesis initiation factors elF4GI and II, elF4B, elF3(p35) and elF2 $\alpha$, leading to inhibition of translation. In addition, the elF2 $\alpha$ kinase PKR can be activated by a FADD-dependent pathway. PKR is involved in the phosphorylation of both elF $2 \alpha$ and NF- $\kappa$ B, either or both of which may contribute to the regulation of apoptosis. Finally, the activation of the JNK and p38 stress kinase pathways (by caspase cleavage-dependent activation of PAK2 and MEKK1 and/or by the Daxx kinase pathway) can control both protein synthesis (perhaps via phosphorylation of elF4E) and cell death itself. For further details see the text an active tetrameric caspase- 8 complex $(\mathrm{p} 18 / \mathrm{p} 10)_{2}$ is released into the cytosol. ${ }^{10,14,84,85,88,89}$ This enzyme then initiates the death cascade by proteolytic activation of downstream targets such as caspase- 6 and caspase$3^{85,89,92-94}$ and other substrates. ${ }^{95,96}$ These events ultimately result in the loss of mitochondrial integrity, the release of cytochrome $c$ and the activation of caspase- 9 via interaction of the latter with Apaf-1. ${ }^{10,84,85}$ Numerous studies have demonstrated that the inhibition of caspase8 activity is sufficient to prevent CD95-induced apoptosis. ${ }^{10,84,92,93,97}$ However caspase-3, which is also activated by a variety of other death stimuli, plays a major role as downstream executioner in the apoptotic pathway, both in the cytoplasm and the nucleus. ${ }^{10,13,84,85,96,98-100}$ Irreparable damage to the genome caused by mutagens, pharmaceuticals that inhibit DNA repair or ionising radiation also leads to apoptosis, primarily via activation of caspase-9. ${ }^{101}$

In the last few years it has also become increasingly clear that the elF2 $\alpha$ kinase $\mathrm{PKR}^{102}$ is capable of contributing to caspase-dependent apoptosis in cells treated with interferons or double-stranded RNA (dsRNA), or following cell stress. ${ }^{103-107}$ It has been suggested that PKR may act as a 'receptor/inducer' for dsRNA signalling, having inputs into the apoptotic pathways at more than one level. ${ }^{108,109}$ One input is via the phosphorylation of elF $2 \alpha,{ }^{105,106}$ with TNF $\alpha$-induced apoptosis being partially prevented by the over-expression of a non-phosphorylatable form of elF2 $\alpha$. Consistent with this, the forced overexpression of a mutant elF2 $\alpha$ (S51D), which mimics phosphorylation at position Ser51, was sufficient to induce apoptosis in COS-1 cells. ${ }^{105}$ At another level, the PKRdependent cellular response to dsRNA has been shown to require the activity of FADD, and it has been suggested that PKR may promote DISC formation. ${ }^{109}$ In addition, signalling through $\mathrm{NF}-\kappa \mathrm{B}$ and $\mathrm{p} 53$ may also have a role to play in PKR-induced apoptosis. ${ }^{105,110-113}$

Evidence also points to the importance of several other protein phosphorylation events in the induction and regulation of apoptosis. Although there appears to be no conclusive evidence that kinases are required for the execution of the cell death programme, these enzymes may impinge upon the death machinery by amplifying or integrating incoming signals to swing the balance between cell survival and cell death. During apoptosis several protein kinases are cleaved and enzymatically activated, including MEK kinase 1 (MEKK-1), p21-activated kinase 2 (PAK2) and protein kinase $\mathrm{C}-\delta$ (PKC- $\delta) .{ }^{96}$ Cleavageactivation of MEKK-1 and PKC- $\delta$ probably contributes to cell death by altering the substrate specificity and subcellular localisation of these kinases in dying cells, and PAK2 can activate stress signalling pathways. 96,114-116 The caspase-dependent cleavage of signalling proteins essential for cell survival has also been examined, ${ }^{96}$ with the cleavage of Raf- 1 and Akt (PKB) kinases impairing their activity and leading to the inhibition of cell survival signalling pathways. ${ }^{85,117,118}$ Treatment of haemopoietic cells with survival factors (such as IGF-1 and IL-3) results in the activation of the phosphoinositide- 3 kinase pathway, culminating in the Akt-mediated phosphorylation 
of the pro-apopotic proteins BAD and caspase-9. ${ }^{85,117-119}$ Phosphorylation maintains caspase- 9 in an inactive state and allows BAD to interact with a 14-3-3 protein, such that it is retained in the cytoplasm as an inactive heterodimer, promoting cell survival. Conversely, dephosphorylation of BAD mediated by calcineurin induces apoptosis. ${ }^{120}$

In Jurkat cells, CD95-mediated inhibition of signalling via the Akt pathway has been associated with decreased phosphorylation and cleavage of both $\mathrm{p} 70^{\mathrm{S} 6 \mathrm{~K}}$ and the elF4E-binding protein 1 (4E-BP1) (S Morley, unpublished data). Down-regulation of $\mathrm{p} 70^{\mathrm{S} 6 \mathrm{~K}}$ would be predicted to result in a decrease in the translation of mRNAs containing a $5^{\prime}$ polypyrimidine tract, ${ }^{121}$ while the dephosphorylation of 4E-BP1 should result in the sequestration of elF4E away from elF4G and a general inhibition of translation (reviewed in 22,25,122-124).

The roles of the mitogen-activated protein kinase (MAPK) signalling pathways in the control of apoptosis are more controversial. Activation of the ERK MAP kinase has been generally associated with cell survival, ${ }^{125}$ with inhibition of this pathway found to sensitize HeLa cells to CD95-mediated apoptosis. ${ }^{126}$ Surprisingly, ERK kinase is transiently activated by CD95 stimulation during apoptosis, ${ }^{96,126}$ but it is then down-regulated following the cleavage of Raf-1. ${ }^{96}$ In contrast, the p38 MAP kinase and c-jun N-terminal kinases (JNK) 94,97,127-132 are strongly activated in a caspase-dependent manner during apoptosis, and have been implicated as possible mediators of the apoptotic process. ${ }^{94,97,131,133}$ Their activation may occur via numerous possible routes which include: JNK activation following the recruitment of Daxx kinase rather than FADD to the activated CD95 receptor; ${ }^{134}$ activation via the cleaved, activated forms of MEKK-1 or PAK2, which are downstream of caspases but upstream of $\mathrm{JNK},{ }^{96,133,135}$ resulting in amplification of apoptotic signals; or activation through typical signalling pathways utilising Ras and Rac. ${ }^{136}$ However, the story does not seem to be a simple one and mechanisms may be cell-type specific. For instance, signalling through the p38 MAP kinase pathway has been implicated as a requirement for cell survival in response to TNF $\alpha^{135}$ and inhibition of the p38 pathway has been reported to induce apoptosis. ${ }^{132}$ Furthermore, p38 and/or JNK activities are not required for apoptosis in all cell types. ${ }^{137-139}$

Several lines of evidence suggest that the phosphorylation of elF4E can be associated with the stimulation of translation initiation and that elF4E phosphorylation is decreased when protein synthesis rates are depressed (reviewed in ${ }^{25,122-124}$ ). The phosphorylation of elF4E is mediated via the activation of the ERK and/or p38 MAP kinase signalling pathways, which recruit and activate the enzyme Mnk1. This kinase, which interacts with elF4G, can phosphorylate elF4E at the physiological site in vitro and in vivo. However, in spite of the fact that these kinase cascades are activated in CD95-stimulated Jurkat cells, they do not bring about the phosphorylation of elF4E; on the other hand, etoposide-induced apoptosis does result in a robust phosphorylation of elF4E. ${ }^{69}$ The reasons for these discrepancies are unclear but may reflect differential regulation of elF4E phosphatase activity. Indeed, Santoro et al. ${ }^{100}$ have shown that phosphatase $2 \mathrm{~A}$ is cleaved and activated during apoptosis and this activity may have a role in preventing elF4E phosphorylation, thus potentiating the inhibition of translation. Further work is required to address this possibility.

\section{Mechanisms of regulation of protein synthesis during apoptosis}

As indicated above, the progress of apoptosis is characterized by a complex programme of changes involving several initiation factors. This programme includes the specific fragmentation of certain factors and alterations in the state of phosphorylation or state of association with binding proteins of others (Table 1). Any or all of these events can potentially contribute to the inhibition of protein synthesis that is seen under these conditions and it is likely that the relative importance of the various changes may be different at distinct stages of development of the apoptotic response.

One of the earliest effects of apoptotic inducers is an increase in the phosphorylation of elF $2 \alpha$. This effect may in some cases be transient but could be responsible for the very early inhibition of protein synthesis. As well as becoming phosphorylated elF $2 \alpha$ can also be cleaved to give rise to a C-terminally truncated form, elF2 $\alpha \Delta \mathrm{C}$. $^{77,78}$ Although it can still be phosphorylated by PKR elF2 $\alpha \Delta \mathrm{C}$ has been reported to block the PKR-mediated suppression of reporter gene expression. ${ }^{78}$ Thus the caspase-mediated cleavage of elF2 $\alpha$ may provide a mechanism for reversing the effects of phosphorylation on the function of initiation factor elF2.

Cleavage of elF4G is also a relatively early event and our data indicate that a modified form of elF4F, containing elF4E and elF4A but with the central M-FAG fragment in place of full-length elF4GI, is present for at least several hours in apoptosing cells (Figure 5). Unlike the situation in picornavirus-infected cells, where cleavage of elF4G separates the site that interacts with elF4E from other functional regions, ${ }^{34,59,63,140}$ the 'mini-elF4F' present in apoptotic cells may still be able to support some capdependent initiation (Figure 5). Consistent with this, the MFAG fragment of elF4GI remains associated with ribosomes in apoptotic cells. ${ }^{75}$ Recent reports have shown that a central core domain of elF4G can still recruit ribosomes to mRNA for cap-dependent translation. ${ }^{141,142}$ This can occur in the absence of both the $\mathrm{N}$-terminal and $\mathrm{C}$-terminal regions of the protein, which are required for the binding of other factors such as PABP and Mnk1 respectively. We have suggested that the M-FAG-containing form of elF4F will be deficient in PABP-dependent mRNA circularization and re-initiation activity ${ }^{37}$ since M-FAG does not contain the PABP binding site ${ }^{68,75}$ (see Figures 3 and 5). The decrease in the phosphorylation state of elF4E during apoptosis may also be a consequence of elF4G cleavage because the binding site for the elF4E kinase, Mnk1, is not present in MFAG.

It is also possible that one or more of the elF4G cleavage fragments may show a gain of function. For example N-FAG, which can be stable in apoptosing cells for at least $24 \mathrm{~h},{ }^{70}$ may impair poly(A)-dependent initiation 
or its regulation by sequestering $\mathrm{PABP},{ }^{29}$ and $\mathrm{C}-\mathrm{FAG}$ may interfere with elF4E phosphorylation by titrating out Mnk1. ${ }^{38}$ In this connection it is of interest that a fragment of a gene variously called p97, DAP5 or NAT1, ${ }^{143-145}$ that encodes a mammalian homologue of the central part of elF4GI, acted in a dominant negative fashion to protect $\mathrm{HeLa}$ cells against interferon- $\gamma$-induced apoptosis. ${ }^{144}$ This suggested that full-length p97/DAP5 may itself be pro-apoptotic. The protein can bind both elF4A and elF3 and inhibits
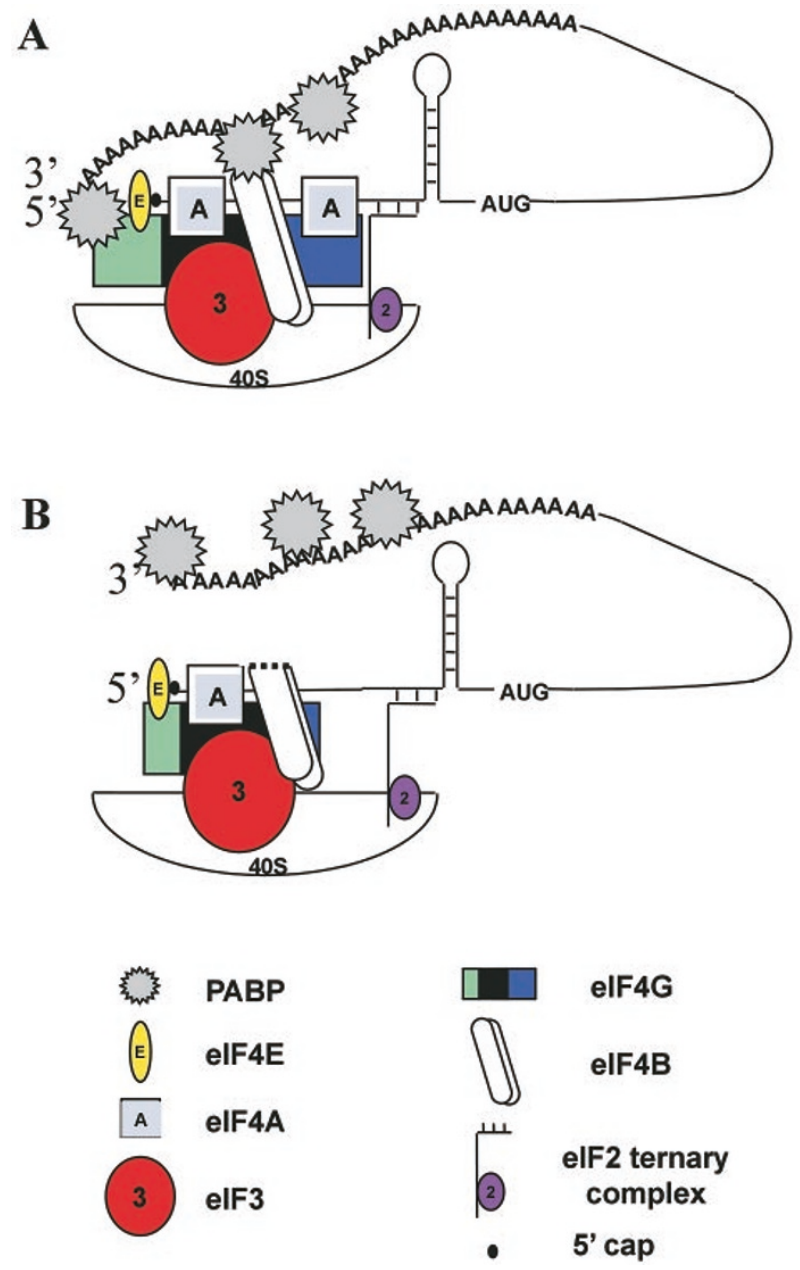

Figure 5 Modifications to the 40S ribosomal initiation complex as a result of initiation factor cleavages in apoptotic cells. (A) In non-apoptotic cells a complex pattern of interactions between several initiation factors and between these factors and either the mRNA or the ribosome results in the formation of the complex shown. Note that the $5^{\prime}$ end of the mRNA is bound to elF4E (yellow) via the cap structure (small black circle) whilst the $3^{\prime}$ end of the mRNA interacts with $\mathrm{PABP}$ (shaded star symbol) via the poly $(\mathrm{A})$ tail. Since both elF4E and PABP interact with elF4G this effectively leads to 'circularisation' of the mRNA. The sizes of the various components are not drawn to scale. Modified from Figure 1 of reference ${ }^{25}$. (B) In apoptotic cells the initiation complex is likely to be modified in several ways. elF4G is cleaved to generate the fragment M-FAG, which retains the ability to bind elF4E and elF3 (and hence the $5^{\prime}$ end of $\mathrm{mRNA}$ and the $40 \mathrm{~S}$ ribosomal subunit) but loses the interaction with PABP. elF4B is truncated at its $\mathrm{N}$-terminus, also leading to loss of PABP interaction (M Bushell and SJ Morley, unpublished data). As a result of these changes mRNA circularisation is likely to be impaired, with consequent loss of the efficiency of translational reinitiation. For other changes associated with apoptosis (not shown here) please see the text translation when overexpressed in transfected cells. ${ }^{143,145}$ Although M-FAG still possesses the elF4E binding site, which is missing from p97/DAP5, it otherwise has some resemblance to the latter (32\% sequence identity). C-FAG also has regions of homology with p97/DAP5 (25\% sequence identity). It is possible therefore that one or both fragments may function in a comparable pro-apoptotic manner to p97/DAP5.

We have reported elsewhere ${ }^{77}$ that the fragment of elF4B which is generated in apoptotic cells retains the domain required for self-association and for interaction with elF3. ${ }^{146}$ The cleaved elF4B can also still interact with the cap binding complex. It is too early to say whether the cleavage of elF4B has functional significance but this issue is currently being addressed in our laboratories. There is an essential RNA-binding domain close to the $\mathrm{N}$-terminus of elF4B ${ }^{146,147}$ and the caspase-3-mediated cleavage which occurs at a site adjacent to this motif may impair function. Similarly, although the role of the p35 subunit of elF3 in the function of this multi-subunit factor remains unknown, ${ }^{148}$ and it is not possible to predict the consequences of the caspase-mediated cleavage of elF3(p35) during apoptosis, the possibility that p35 cleavage contributes to the downregulation of translation cannot be ruled out.

\section{Potential physiological consequences of changes in the protein synthetic machinery associated with apoptosis}

Studies of the responses of a large variety of cell systems to many different physiological controls have shown that protein synthesis can be modulated by both changes in the state of phosphorylation of initiation factors and changes in the levels of these factors in the cell. These effects allow rapid modification of the overall rate of translation as well as posttranscriptional regulation of gene expression due to changes in the relative selection of different mRNA species. The key proteins that have most often been associated with the control of initiation are elF2/elF2B, elF4E/4E-BPs and elF4G. Overexpression of elF4E, elF4G or a non-phosphorylatable form of elF2 $\alpha$ in NIH-3T3 cells results in transformation to a malignant phenotype $^{149-151}$ (reviewed in ${ }^{152,153}$ ). The mechanisms responsible could include the enhanced translation of inefficient mRNAs ${ }^{154}$ and/or the inability of the cell to downregulate translation in response to negative regulators. Consistent with this, down-regulation of elF4E strongly inhibits protein synthesis, decreases cell growth and impairs malignancy. ${ }^{155,156}$ (Note, however, that the level of elF4G can also fall dramatically when elF4E is depleted, ${ }^{155}$ so it is not possible to say which factor is more important in bringing about these effects). High levels of expression of elF4E and elF4G have been found in various human tumours. ${ }^{157-160}$

In view of these observations it is important to establish the molecular mechanisms by which changes in the levels or activities of the key polypeptide chain initiation factors affect the phenotype of the cell. In the case of elF4G we know that truncated forms of the protein retain various biological activities, such as the ability to support capindependent and/or internal initiation, ${ }^{63,141,161}$ and it is possible that the selective regulation of gene expression 
at the translational level is perturbed by the accumulation of elF4G cleavage products during apoptosis. Several cellular mRNAs are now known to be capable of translation by mechanisms other than the standard cap-dependent process under certain conditions. ${ }^{30,49,56,162}$ It is therefore of considerable interest that the mRNAs encoding a number of proteins associated with cell death such as the inhibitor of apoptosis XIAP, the c-myc oncogene and the pro-apoptotic proteins p97/DAP5 and Apaf-1 fall into this category $^{52,76,163}$ (and AE Willis, personal communication). Furthermore the translation of these mRNAs appears to be resistant to the general inhibition of protein synthetic activity that occurs in apoptosing cells. In the case of p97/DAP5 recent evidence ${ }^{76}$ additionally indicates that this protein (which itself is a substrate for cleavage during apoptosis) can enhance its own IRES-mediated translation. Enhanced expression of proteins of the IAP family ${ }^{164,165}$ would be expected to limit the apoptotic response, whereas synthesis of p97/DAP5 or Apaf-1 would have the opposite effect, providing a positive feedback and accelerating apoptosis. Which of these outcomes predominates might depend on the cell type, its state of differentiation and other conditions (see for example ${ }^{166}$ ). Further work is required to address the possible roles of the elF4GI fragments N-FAG, M-FAG or C-FAG in mediating cap-dependent and/or -independent translation in apoptosing cells and to determine whether the continued translation of specific mRNAs such as those described above is influenced by these proteins.

Finally, consideration needs to be given to the possible relationship between the initiation factor cleavages that occur during apoptosis and the development of autoimmunity. Causal links between dysregulation of apoptosis and some autoimmune diseases have been proposed, ${ }^{167}$ and it has been suggested that some caspase substrates may function as autoantigens. ${ }^{168}$ It is certainly the case that some RNA binding proteins that may be involved in translational regulation, such as the La antigen, ${ }^{169,170}$ are frequently found to be targets for autoimmune antibodies. A recent report ${ }^{171}$ indicates that the La protein is indeed both dephosphorylated and cleaved during apoptosis. This protein is also a target for cleavage by the cytotoxic $T$ lymphocyte-derived enzyme granzyme B. ${ }^{172}$ However as yet there are no reports of elF4G or other caspase- or granzyme B-cleavable protein synthesis factors acting as autoantigens in human disease.

\section{Acknowledgements}

Research in our laboratories is supported by grants from the Wellcome Trust (grants 040800, 045619 and 056778), the Leukaemia Research Fund, the Cancer Prevention Research Trust and Glaxo-Wellcome. SJ Morley is a Senior Research Fellow of the Wellcome Trust.

\section{References}

1. Jarpe MB, Widmann C, Knall C, Schlesinger TK, Gibson S, Yujiri T, Fanger GR, Gelfand EW and Johnson GL (1998) Anti-apoptotic versus pro-apoptotic signal transduction: Checkpoints and stop signs along the road to death. Oncogene 17: $1475-1482$

2. Rowan S and Fisher DE (1997) Mechanisms of apoptotic cell death. Leukemia 11: $457-465$
3. Nagata S (1997) Apoptosis by death factor. Cell 88: $355-365$

4. Rathmell JC and Thompson CB (1999) The central effectors of cell death in the immune system. Annu. Rev. Immunol. 17: 781-828

5. Wolf BB and Green DR (1999) Suicidal tendencies: Apoptotic cell death by caspase family proteinases. J. Biol. Chem. 274: 20049-20052

6. Wallach D, Varfolomeev EE, Malinin NL, Goltsev YV, Kovalenko AV and Boldin MP (1999) Tumor necrosis factor receptor and Fas signaling mechanisms. Annu. Rev. Immunol. 17: 331-367

7. Kischkel FC, Hellbardt S, Behrmann I, Germer M, Pawlita M, Krammer PH and Peter ME (1995) Cytotoxicity-dependent APO-1 (Fas/CD95)-associated proteins form a death-inducing signalling complex (DISC) with the receptor. EMBO J. 14: $5579-5588$

8. Medema JP, Scaffidi C, KischkelFC, Shevchenko A, Mann M, KrammerPH and Peter ME (1997) FLICE is activated by association with the CD95 deathinducing signaling complex (DISC). EMBO J. 16: 794-804

9. Cain K, Brown DG, Langlais C and Cohen GM (1999) Caspase activation involves the formation of the aposome, a large (similar to $700 \mathrm{kDa}$ ) caspaseactivating complex. J. Biol. Chem. 274: 22686-22692

10. Cohen GM (1997) Caspases: the executioners of apoptosis. Biochem. J. 326: $1-16$

11. Kidd VJ (1998) Proteolytic activities that mediate apoptosis. Annu. Rev. Physiol. 60: 533-573

12. Nuñez G, Benedict MA, Hu YM and Inohara N (1998) Caspases: the proteases of the apoptotic pathway. Oncogene 17: 3237-3245

13. Sun XM, MacFarlane M, Zhuang JG, Wolf BB, Green DR and Cohen GM (1999) Distinct caspase cascades are initiated in receptor-mediated and chemicalinduced apoptosis. J. Biol. Chem. 274: 5053-5060

14. Salvesen GS and Dixit VM (1999) Caspase activation: the induced-proximity model. Proc. Natl. Acad. Sci. USA 96: 10964-10967

15. Peter ME and Krammer PH (1998) Mechanisms of CD95 (APO-1/Fas)mediated apoptosis. Curr. Opin. Immunol. 10: 545-551

16. McCarthy NJ, Whyte MKB, Gilbert CS and Evan GI (1997) Inhibition of Ced-3/ ICE-related proteases does not prevent cell death induced by oncogenes, DNA damage, or the Bcl-2 homologue Bak. J. Cell Biol. 136: 215-227

17. Borner $C$ and Monney L (1999) Apoptosis without caspases: an inefficient molecular guillotine. Cell Death Differ. 6: 497-507

18. Kitanaka $C$ and Kuchino $Y$ (1999) Caspase-independent programmed cell death with necrotic morphology. Cell Death Differ. 6: 508-515

19. Kawahara A, Ohsawa $Y$, Matsumura H, Uchiyama $Y$ and Nagata S (1998) Caspase-independent cell killing by Fas-associated protein with death domain. J. Cell Biol. 143: 1353-1360

20. Déas O, Dumont C, MacFarlane M, Rouleau M, Hebib C, Harper F, Hirsch F, Charpentier B, Cohen GM and Senik A (1998) Caspase-independent cell death induced by anti-CD2 or staurosporine in activated human peripheral $T$ lymphocytes. J. Immunol. 161: 3375-3383

21. Xiang J, Chao DT and Korsmeyer SJ (1996) BAX-induced cell death may not require interleukin $1 \beta$-converting enzyme-like proteases. Proc. Natl. Acad. Sci. USA 93: $14559-14563$

22. Pain VM (1996) Initiation of protein synthesis in eukaryotic cells. Eur. J. Biochem. 236: 747-771

23. Merrick WC and Hershey JWB (1996) The pathway and mechanism of protein synthesis. In Translational control, HersheyJWB, Mathews MB and Sonenberg $\mathrm{N}$, eds (Cold Spring Harbor, New York: Cold Spring Harbor Laboratory Press) pp. $31-70$

24. Kimball SR (1999) Eukaryotic initiation factor elF2. Int. J. Biochem. Cell Biol. 31: $25-29$

25. Morley SJ, Curtis PS and Pain VM (1997) elF4G: Translation's mystery factor begins to yield its secrets. RNA Publ. RNA Soc. 3: 1085-1104

26. Keiper BD, Gan WN and Rhoads RE (1999) Protein synthesis initiation factor 4G. Int. J. Biochem. Cell Biol. 31: 37-41

27. Hentze M (1997) elF4G: A multipurpose ribosome adaptor? Science 275:500 501

28. Yan R, Rychlik W, Etchison D and Rhoads RE (1992) Amino acid sequence of the human protein synthesis initiation factor elF-4gamma. J. Biol. Chem. 267: $23226-23231$

29. Imataka H, Gradi A and Sonenberg N (1998) A newly identified N-terminal amino acid sequence of human elF4G binds poly(A)-binding protein and functions in poly(A)-dependent translation. EMBO J. 17: 7480-7489 
30. Johannes G and Sarnow P (1998) Cap-independent polysomal association of natural mRNAs encoding c-myc, BiP, and elF4G conferred by internal ribosome entry sites. RNA Publ. RNA Soc. 4: 1500-1513

31. Merrick WC (1994) Eukaryotic protein synthesis: An in vitro analysis. Biochimie 76: $822-830$

32. Gradi A, Imataka H, Svitkin YV, Rom E, Raught B, Morino S and Sonenberg N (1998) A novel functional human eukaryotic translation initiation factor 4G. Mol. Cell. Biol. 18: 334-342

33. Mader S, Lee H, Pause A and Sonenberg N (1995) The translation initiation factor elF-4E binds to a common motif shared by the translation factor elF$4 \mathrm{gamma}$ and the translational repressors $4 \mathrm{E}$-binding proteins. Mol. Cell. Biol. 15: $4990-4997$

34. Lamphear BJ, Kirchweger R, Skern T and Rhoads RE (1995) Mapping of functional domains in eukaryotic protein synthesis initiation factor $4 \mathrm{G}$ (elF4G) with picornaviral proteases -Implications for cap-dependent and capindependent translational initiation. J. Biol. Chem. 270: 21975-21983

35. Tarun Jr SZ, and Sachs AB (1996) Association of the yeast poly $(A)$ tail binding protein with translation initiation factor elF-4G. EMBO J. 15: 7168-7177

36. Le H, Tanguay RL, Balasta ML, Wei CC, Browning KS, Metz AM, Goss DJ and Gallie DR (1997) Translation initiation factors elF-iso4G and elF-4B interact with the poly(A)-binding protein and increase its RNA binding activity. J. Biol. Chem. 272: 16247-16255

37. Tarun Jr SZ, Wells SE, Deardorff JA and Sachs AB (1997) Translation initiation factor elF4G mediates in vitro poly(A) tail-dependent translation. Proc. Natl. Acad. Sci. USA 94: 9046-9051

38. Pyronnet S, Imataka H, Gingras AC, Fukunaga R, Hunter T and Sonenberg N (1999) Human eukaryotic translation initiation factor 4G (elF4G) recruits Mnk1 to phosphorylate elF4E. EMBO J. 18: 270-279

39. Haghighat A and Sonenberg N(1997) elF4G dramatically enhances the binding of elF4E to the mRNA 5'-cap structure. J. Biol. Chem. 272: 21677-21680

40. Mader S, Lee H, Pause A and Sonenberg N (1995) The translation initiation factor elF-4E binds to a common motif shared by the translation factor elF4 gamma and the translational repressors $4 \mathrm{E}$-binding proteins. Mol. Cell. Biol. 15: $4990-4997$

41. Haghighat A, Mader S, Pause A and Sonenberg N (1995) Repression of capdependent translation by $4 \mathrm{E}$-binding protein 1: Competition with p220 for binding to eukaryotic initiation factor-4E. EMBO J. 14: 5701-5709

42. Altmann M, Schmitz N, Berset C and Trachsel H (1997) A novel inhibitor of capdependent translation initiation in yeast: $\mathrm{P} 20$ competes with elF4G for binding to elF4E. EMBO J. 16: 1114-1121

43. Matsuo H, Li HJ, McGuire AM, Fletcher CM, Gingras AC, Sonenberg N and Wagner $G$ (1997) Structure of translation factor elF4E bound to $m^{7}$ GDP and interaction with 4E-binding protein. Nature Struct. Biol. 4: 717-724

44. Lawrence JC and Abraham RT (1997) PHAS/4E-BPs as regulators of mRNA translation and cell proliferation. Trends Biochem. Sci. 22: 345-349

45. Graves LM, Bornfeldt KE, Argast GM, Krebs EG, Kong X, Lin TA and Lawrence Jr JC (1995) CAMP- and rapamycin-sensitive regulation of the association of eukaryotic initiation factor 4E and the translational regulator PHAS-I in aortic smooth muscle cells. Proc. Natl. Acad. Sci. USA 92: 7222-7226

46. Von Manteuffel SR, Gingras AC, Ming XF, Sonenberg N and Thomas G (1996) $4 \mathrm{E}-\mathrm{BP} 1$ phosphorylation is mediated by the FRAP-p $70^{\mathrm{s} 6 \mathrm{k}}$ pathway and is independent of mitogen-activated protein kinase. Proc. Natl. Acad. Sci. USA 93: $4076-4080$

47. Brunn GJ, Hudson CC, Sekulic A, Williams JM, Hosoi H, Houghton PJ, Lawrence Jr JC and Abraham RT (1997) Phosphorylation of the translational repressor PHAS-I by the mammalian target of rapamycin. Science 277: 99 101

48. Gingras AC, Gygi SP, Raught B, Polakiewicz RD, Abraham RT, Hoekstra MF, Aebersold Rand Sonenberg N (1999) Regulation of 4E-BP1 phosphorylation: a novel two-step mechanism. Genes Dev. 13: 1422-1437

49. Stoneley M, Paulin FEM, Le Quesne JPC, Chappell SA and Willis AE (1998) CMyc $5^{\prime}$ untranslated region contains an internal ribosome entry segment. Oncogene 16: 423-428

50. Stein I, Itin A, Einat P, Skaliter R, Grossman Z and Keshet E (1998) Translation of vascular endothelial growth factor mRNA by internal ribosome entry: Implications for translation under hypoxia. Mol. Cell. Biol. 18: 3112-3119

51. Van der Velden AW and Thomas AAM (1999) The role of the $5^{\prime}$ untranslated region of an $\mathrm{mRNA}$ in translation regulation during development. Int. J. Biochem. Cell Biol. 31: 87-106
52. Holcik M, Lefebvre C, Yeh C, Chow T and Korneluk RG (1999) A new internalribosome-entry-site motif potentiates XIAP-mediated cytoprotection. Nature Cell Biol. 1: 190-192

53. Scharnhorst V, Dekker P, van der Eb AJ and Jochemsen AG (1999) Internal translation initiation generates novel WT1 protein isoforms with distinct biological properties. J. Biol. Chem. 274: 23456-23462

54. Bernstein J, Sella O, Le SY and Elroy-Stein O (1997) PDGF2/c-sis mRNA leadercontains a differentiation-linked internal ribosomal entry site (D-IRES). J. Biol. Chem. 272: 9356-9362

55. Sella O, Gerlitz G, Le SY and Elroy-Stein O (1999) Differentiation-induced internal translation of c-sis mRNA: Analysis of the cis elements and their differentiation-linked binding to the hnRNP C protein. Mol. Cell. Biol. 19:54295440

56. Willis AE (1999) Translational control of growth factor and proto-oncogene expression. Int. J. Biochem. Cell Biol. 31: 73-86

57. Hann SR (1995) Methionine deprivation regulates the translation of functionally-distinct c-Myc proteins. Adv. Exp. Med. Biol. 375: 107-116

58. Spotts GD, Patel SV, Xiao Q and Hann SR (1997) Identification of downstreaminitiated c-Myc proteins which are dominant-negative inhibitors of transactivation by full-length c-Myc proteins. Mol. Cell. Biol. 17: 1459-1468

59. Lamphear BJ, Yan R, Yang F, Waters D, Liebig H-D, Klump H, Kuechler E, Skern T and Rhoads RE (1993) Mapping the cleavage site in protein synthesis initiation factor elF-4gamma of the $2 \mathrm{~A}$ proteases from human Coxsackievirus and rhinovirus. J. Biol. Chem. 268: 19200-19203

60. Gradi A, Svitkin YV, Imataka H and Sonenberg N (1998) Proteolysis of human eukaryotic translation initiation factor elF4GII, but not elF4GI, coincides with the shutoff of host protein synthesis after poliovirus infection. Proc. Natl. Acad. Sci. USA 95: $11089-11094$

61. Svitkin YV, Gradi A, Imataka H, Morino S and Sonenberg N (1999) Eukaryotic initiation factor 4GII (elF4GII), but not elF4GI, cleavage correlates with inhibition of host cell protein synthesis after human rhinovirus infection. J. Virol. 73: $3467-3472$

62. Gradi A, Svitkin YV, Imataka H and Sonenberg N (1998) Proteolysis of human eukaryotic translation initiation factor elF4GII, but not elF4GI, coincides with the shutoff of host protein synthesis after poliovirus infection. Proc. Natl. Acad. Sci. USA 95: $11089-11094$

63. Ohlmann T, Rau M, Pain VM and Morley SJ (1996) The C-terminal domain of eukaryotic protein synthesis initiation factor (elF)4G is sufficient to support capindependent translation in the absence of elF4E. EMBO J. 15: 1371-1382

64. Pestova TV, Shatsky IN and Hellen CUT (1996) Functional dissection of eukaryotic initiation factor $4 \mathrm{~F}$ : The $4 \mathrm{~A}$ subunit and the central domain of the $4 \mathrm{G}$ subunit are sufficient to mediate internal entry of $43 \mathrm{~S}$ preinitiation complexes. Mol. Cell. Biol. 16: 6870-6878

65. DeGracia DJ, Neumar RW, White BC and Krause GS (1996) Global brain ischemia and reperfusion: Modifications in eukaryotic initiation factors associated with inhibition of translation initiation. J. Neurochem. 67: 20052012

66. Benton PA, Barrett DJ, Matts RL and Lloyd RE (1996) The outcome of poliovirus infection in K562 cells is cytosolic rather than persistent after hemin-induced differentiation. J. Virol. 70: 5525-5532

67. Deckwerth TL and Johnson EM (1993) Temporal analysis of events associated with programmed cell death (apoptosis) of sympathetic neurons deprived of nerve growth factor. J. Cell Biol. 123: 1207-1222

68. Clemens MJ, Bushell M and Morley SJ (1998) Degradation of eukaryotic polypeptide chain initiation factor (elF) $4 \mathrm{G}$ in response to induction of apoptosis in human lymphoma cell lines. Oncogene 17: 2921-2931

69. Morley SJ, McKendrick L and Bushell M (1998) Cleavage of translation initiation factor 4G (eIF4G) during anti-Fas IgM-induced apoptosis does not require signalling through the p38 mitogen-activated protein (MAP) kinase. FEBS Lett. 438: $41-48$

70. Marissen WE and Lloyd RE (1998) Eukaryotic translation initiation factor $4 \mathrm{G}$ is targeted for proteolytic cleavage by caspase 3 during inhibition of translation in apoptotic cells. Mol. Cell. Biol. 18: 7565-7574

71. Scott CE and Adebodun F (1999) ${ }^{13} \mathrm{C}-\mathrm{NMR}$ investigation of protein synthesis during apoptosis in human leukemic cell lines. J. Cell. Physiol. 181: 147-152

72. Zhou BB, Li HL, Yuan JY and Kirschner MW (1998) Caspase-dependent activation of cyclin-dependent kinases during fas-induced apoptosis in Jurkat cells. Proc. Natl. Acad. Sci. USA 95: 6785-6790 
73. Degen WGJ, Pruijn GJM and van Venrooij WJ (2000) Caspase-dependent cleavage of nucleic acids. Cell Death Differ. 7: 616-627

74. Bushell M, McKendrick L, Janicke RU, Clemens MJ and Morley SJ (1999) Caspase- 3 is necessary and sufficient for cleavage of protein synthesis eukaryotic initiation factor $4 G$ during apoptosis. FEBS Lett. 451: 332-336

75. Bushell M, Poncet D, Marissen WE, Flotow H, Lloyd RE, Clemens MJ and Morley SJ (2000) Cleavage of polypeptide chain initiation factor elF4GI during apoptosis in lymphoma cells: Characterisation of an internal fragment generated by caspase-3-mediated cleavage. Cell Death Differ. 7: 628-636

76. Henis-Korenblit S, Levy Strumpf N, Goldstaub D and Kimchi A (2000) A novel form of DAP5 protein accumulates in apoptotic cells as a result of caspase cleavage and internal ribosome entry site-mediated translation. Mol. Cell. Biol. 20: $496-506$

77. Bushell M, WoodW, Clemens MJand Morley SJ (2000) Changes in integrity and association of eukaryotic protein synthesis factors during apoptosis. Eur. J. Biochem. 267: 1083-1091

78. Satoh S, Hijikata M, Handa H and Shimotohno K (1999) Caspase-mediated cleavage of eukaryotic translation initiation factor subunit $2 \alpha$. Biochem. J. 342 $65-70$

79. Beretta L, Singer NG, Hinderer R, Gingras AC, Richardson B, Hanash SM and Sonenberg $N$ (1998) Differential regulation of translation and elF4E phosphorylation during human thymocyte maturation. J. Immunol. 160: 3269-3273

80. Yonehara S, Ishii A and Yonehara M (1989) A cell-killing monoclonal antibody (anti-Fas) to a cell surface antigen co-downregulated with the receptor of tumor necrosis factor. J. Exp. Med. 169: 1747-1756

81. Itoh N, Yonehara S, Ishii A, Yonehara M, Mizushima S, Sameshima M, Hase A, Seto $Y$ and Nagata S (1991) The polypeptide encoded by the CDNA for human cell surface antigen Fas can mediate apoptosis. Cell 66: 233-243

82. Gjertsen BT and Doskeland SO (1995) Protein phosphorylation in apoptosis. Biochim. Biophys. Acta Mol. Cell Res. 1269: 187-199

83. Anderson $\mathrm{P}$ (1997) Kinase cascades regulating entry into apoptosis. Microbiol. Rev. 61: 33-46

84. Schulze-Osthoff K, Ferrari D, Los M, Wesselborg S and Peter ME (1998) Apoptosis signaling by death receptors. Eur. J. Biochem. 254: 439-459

85. Porter AG and Jänicke RU (1999) Emerging roles of caspase-3 in apoptosis. Cell Death Differ. 6: 99-104

86. Chinnaiyan AM, O'Rourke K, Tewari Mand Dixit VM (1995)FADD, a novel death domain-containing protein, interacts with the death domain of Fas and initiates apoptosis. Cell 81: 505-512

87. Boldin MP, Varfolomeev EE, Pancer Z, Mett IL, Camonis JH and Wallach D (1995) A novel protein that interacts with the death domain of Fas/APO1 contains a sequence motif related to the death domain. J. Biol. Chem. 270: $7795-7798$

88. Imai Y, Kimura T, Murakami A, Yajima N, Sakamaki K and Yonehara S (1999) The CED-4-homologous protein FLASH is involved in Fas-mediated activation of caspase-8 during apoptosis. Nature 398: 777-785

89. Ashkenazi A and Dixit VM (1999) Apoptosis control by death and decoy receptors. Curr. Opin. Cell Biol. 11: 255-260

90. Muzio M, Chinnaiyan AM, Kischkel FC, O'Rourke K, Shevchenko A, Ni J, Scaffidi C, Bretz JD, Zhang M, Gentz R, Mann M, Krammer PH, Peter ME and Dixit VM (1996) FLICE, a novel FADD-homologos ICE/CED-3-like protease, is recruited to the $\mathrm{CD} 95$ (Fas/Apo-1) death-inducing signaling complex. Cell 85: 817-827

91. Boldin MP, Goncharov TM, Goltsev YV and Wallach D (1996) Involvement of $\mathrm{MACH}$, a novel MORT1/-FADD-interacting protease, in Fas/Apo-1 and TNF receptor-induced cell death. Cell 85: 803-815

92. Enari M, Hase A and Nagata S (1995) Apoptosis by a cytosolic extract from Fasactivated cells. EMBO J. 14: 5201-5208

93. Enari M, Talanian RV, Wong WW and Nagata S (1996) Sequential activation of ICE-like and CP32-like proteases during Fas-mediated apoptosis. Nature 380: $723-726$

94. Juo P, Kuo CJ, Reynolds SE, Konz RF, Raingeaud J, Davis RJ, Biemann H-P and Blenis J (1997) Fas activation of the p38 mitogen-activated protein kinase signalling pathway requires ICE/CED-3 family proteases. Mol. Cell. Biol. 17: $24-35$

95. Cryns V and Yuan JY (1998) Proteases to die for. Genes Dev. 12: 1551-1570

96. Widmann C, Gibson S and Johnson GL (1998) Caspase-dependentcleavage of signaling proteins during apoptosis - A turn-off mechanism for anti-apoptotic signals. J. Biol. Chem. 273: 7141-7147
97. Juo P, Kuo CJ, Yuan JY and Blenis J (1998) Essential requirement for caspase8/FLICE in the initiation of the Fas-induced apoptotic cascade. Curr. Biol. 8 $1001-1008$

98. Janicke RU, Ng P, Sprengart ML and Porter AG (1998) Caspase-3 is required for $\alpha$-fodrin cleavage but dispensable for cleavage of other death substrates in apoptosis. J. Biol. Chem. 273: 15540-15545

99. Wyllie AH (1997) Apoptosis and carcinogenesis. Eur. J. Cell. Biol. 73: 189-197

100. Santoro MF, Annand RR, Robertson MM, Peng YW, Brady MJ, Mankovich JA, Hackett MC, Ghayur T, Walter G, Wong WW and Giegel DA (1998) Regulation of protein phosphatase $2 \mathrm{~A}$ activity by caspase- 3 during apoptosis. J. Biol. Chem. 273: 13119-13128

101. LiP,Nijhawan D, Budihardjo I, Srinivasula SM, Ahmad M, Alnemri ES and Wang X (1997) Cytochrome $c$ and dATP-dependent formation of Apaf-1/caspase-9 complex initiates an apoptotic protease cascade. Cell 91: 479-489

102. Clemens MJ and Elia A (1997) The double-stranded RNA-dependent protein kinase PKR: Structure and function. J. Interferon Cytokine Res. 17: 503-524

103. Bong Lee $S$ and Esteban M (1994) The interferon-induced double-stranded RNA-activated protein kinase induces apoptosis. Virology 199: 491-496

104. Lee SB, Rodríguez D, Rodríguez JR and Esteban M (1997) The apoptosis pathway triggered by the interferon-induced protein kinase PKR requires the third basic domain, initiates uptream of $\mathrm{Bcl}-2$, and involves ICE-like proteases. Virology 231: $81-88$

105. Srivastava SP, Kumar KU and Kaufman RJ (1998) Phosphorylation of eukaryotic translation initiation factor 2 mediates apoptosis in response to activation of the double-stranded RNA-dependent protein kinase. J. Biol. Chem. 273: 2416-2423

106. Der SD, Yang YL, Weissmann C and Williams BRG (1997) A double-stranded RNA-activated protein kinase-dependent pathway mediating stress-induced apoptosis. Proc. Natl. Acad. Sci. USA 94: 3279-3283

107. Lee SB, Rodríguez D, Rodríguez JR and Esteban M (1997) The apoptosis pathway triggered by the interferon-induced protein kinase PKR requires the third basic domain, initiates upstream of Bcl-2, and involves ICE-like proteases. Virology 231: $81-88$

108. Tan SL and Katze MG (1999) The emerging role of the interferon-induced PKR protein kinase as an apoptotic effector: A new face of death. J. Interferon Cytokine Res. 19: 543-554

109. Balachandran S, Kim CN, Yeh WC, Mak TW, Bhalla K and Barber GN (1998) Activation of the dsRNA-dependent protein kinase, PKR, induces apoptosis through FADD-mediated death signaling. EMBO J. 17: 6888-6902

110. Sonenshein GE (1997) Rel/NF-kappa B transcription factors and the control of apoptosis. Semin. Cancer Biol. 8: 113-119

111. Yeung MC and Lau AS (1998) Tumor suppressor p53 as a component of the tumor necrosis factor-induced, protein kinase PKR-mediated apoptotic pathway in human promonocytic U937 cells. J. Biol. Chem., 273: 2519825202

112. Jagus R, Joshi B and Barber GN (1999) PKR, apoptosis and cancer. Int. J. Biochem. Cell Biol. 31: 123-138

113. GilJ, Alcamí J and Esteban M (1999) Induction of apoptosis by double-stranded -RNA-dependent protein kinase (PKR) involves the a subunit of eukaryotic translation initiation factor 2 and NF-kappaB. Mol. Cell. Biol. 19: 4653-4663

114. Cardone MH, Salvesen GS, Widmann C, Johnson G and Frisch SM (1997) The regulation of anoikis: MEKK-1 activation requires cleavage by caspases. Cell 90: $315-323$

115. Ghayur T, Hugunin M, Talanian RV, Ratnofsky S, Quinlan C, Emoto Y, Pandey P, Datta R, Huang Y, Kharbanda S, Allen H, Kamen R, Wong W and Kufe D (1996) Proteolytic activation of protein kinase C delta by an ICE/CED-3-like protease induces characteristics of apoptosis. J. Exp. Med. 184: 2399-2404

116. Deak JC, Cross JV, Lewis M, Qian YY, Parrott LA, Distelhorst CW and Templeton DJ (1998) Fas-induced proteolytic activation and intracellular redistribution of the stress-signaling kinase MEKK1. Proc. Natl. Acad. Sci. USA 95: $5595-5600$

117. Datta SR, Dudek H, Tao X, Masters S, Fu H, Gotoh Y and Greenberg ME (1997) Akt phosphorylation of BAD couples survival signals to the cell-intrinsic death machinery. Cell 91: 231-241

118. del Peso L, Gonzalez-Garcia M, Page C, Herrera R and Nunez G (1997) Interleukin-3-induced phosphorylation of $B A D$ through the protein kinase Akt. Science 278: 687-689 
119. Cardone MH, Roy N, Stennicke HR, Salvesen GS, Franke TF, Stanbridge E, Frisch S and Reed JC (1998) Regulation of cell death protease caspase- 9 by phosphorylation. Science 282: 1318-1321

120. Wang HG, Pathan N, Ethell IM, Krajewski S, Yamaguchi Y, Shibasaki F McKeon F, Bobo T, Franke TF and Reed JC (1999) Ca2+-induced apoptosis through calcineurin dephosphorylation of BAD. Science 284: 339-343

121. Meyuhas O, Avni D and Sham S (1996) Translational control of ribosomal protein mRNAs in eukaryotes. In Translational Control, Hershey JW, Mathews MB and Sonenberg N, eds (Cold Spring Harbor, New York: Cold Spring Harbor Laboratory Press) pp. 363-388

122. Sonenberg N (1996) mRNA 5' cap-binding protein elF4E and control of cell growth. In Translational Control, Hershey JWB, Mathews MB and Sonenberg N, eds (Cold Spring Harbor: Cold Spring Harbor Laboratory Press) pp. 245269

123. Kleijn M, Scheper GC, Voorma HO and Thomas AAM (1998) Regulation of translation initiation factors by signal transduction. Eur. J. Biochem. 253:531 544

124. Raught $B$ and Gingras AC (1999) elF4E activity is regulated at multple levels. Int. J. Biochem. Cell Biol. 31: 43-57

125. Berra E, Diaz-Meco MT and Moscat J (1998) The activation of p38 and apoptosis by the inhibition of Erk is antagonized by the phosphoinositide 3kinase/Akt pathway. J. Biol. Chem. 273: 10792-10797

126. Holmstrom TH, Tran SE, Johnson VL, Ahn NG, Chow SC and Eriksson JE (1999) Inhibition of mitogen-activated kinase signaling sensitizes HeLa cells to Fas receptor-mediated apoptosis. Mol. Cell. Biol. 19: 5991-6002

127. Cano E and Mahadevan LC (1995) Parallel signal processing among mammalian MAPKs. Trends Biochem. Sci. 20: 117-122

128. Kyriakis JM and Avruch J (1996) Sounding the alarm: protein kinase cascades activated by stress and inflammation. J. Biol. Chem. 271: 24313-24316

129. Kyriakis JM and Avruch J (1996) Protein kinase cascades activated by stress and inflammatory cytokines. Bioessays 18: $567-577$

130. Woodgett JR, Avruch J and Kyriakis J (1996) The stress activated protein kinase pathway. Cancer Surv. 27: 127-138

131. Xia Z, Dickens M, Raingeaud J, Davis RJ and Greenberg ME (1995) Opposing effects of ERK and JNK-p38 MAP kinases on apoptosis. Science 270: $1326-$ 1331

132. Nemoto S, Xiang JL, Huang S and Lin AN (1998) Induction of apoptosis by SB202190 through inhibition of $p 38 \beta$ mitogen-activated protein kinase. J. Biol. Chem. 273: 16415-16420

133. Cahill MA, Peter ME, Kischkel FC, Chinnaiyan AM, Dixit VM, Krammer PH and Nordheim A (1996) CD95 (APO-1/Fas) induces activation of SAP kinases downstream of ICE-like proteases. Oncogene 13: 2087-2096

134. Yang X, Khosravi-Far R, Chang HY and Baltimore D (1997) Daxx, a novel Fasbinding protein that activates JNK and apoptosis. Cell 89: 1067-1076

135. Roulston A, Reinhard C, Amiri P and Williams LT (1998) Early activation of CJun $\mathrm{N}$-terminal kinase and $\mathrm{p} 38$ kinase regulate cell survival in response to tumor necrosis factor $\alpha$. J. Biol. Chem. 273: 10232-10239

136. Brenner B, Koppenhoefer U, Weinstock C, Linderkamp O, Lang Fand Gulbins $E$ (1997) Fas- or ceramide-induced apoptosis is mediated by a rad-regulated activation of jun $\mathrm{N}$-terminal kinase $\mathrm{p} 38$ kinases and GADD153. J. Biol. Chem. 272: $22173-22181$

137. Huang S, Jiang Y, Li Z, Nishida E, Mathias P, Lin S, Ulevitch RJ, Nemerow GR and Han J (1997) Apoptosis signaling pathway in T cells is composed of ICE/ Ced-3 family proteases and MAP kinase kinase 6b. Immunity 6: 739-749

138. Lenczowski JM, Dominguez L, Eder AM, King LB, Zacharchuk CM and Ashwell JD (1997) Lack of a role for Jun kinase and AP-1 in Fas-induced apoptosis. Mol. Cell. Biol. 17: 170-181

139. Low W, Smith A, Ashworth A and Collins M (1999) JNK activation is not required for Fas-mediated apoptosis. Oncogene 18: $3737-3741$

140. Ohlmann T, Pain VM, Wood W, Rau M and Morley SJ (1997) The proteolytic cleavage of eukaryotic initiation factor (eIF) $4 \mathrm{G}$ is prevented by elF4E binding protein (PHAS-I;4E-BP1) in the reticulocyte lysate. EMBO J. 16: 844-855

141. De Gregorio E, Preiss T and Hentze M (1999) Translation driven by an elF4G core domain in vivo. EMBO J. 18: 4865-4874

142. Morino S, Imataka H, Svitkin YV, Pestova TV and Sonenberg N (2000) Eukaryotic translation initiation factor $4 \mathrm{E}$ (elF4E) binding site and the middle one-third of elF4GI constitute the core domain for cap-dependent translation, and the $\mathrm{C}$-terminal one-third functions as a modulatory region. Mol. Cell. Biol. 20: $468-477$
143. Imataka H, Olsen HS and Sonenberg N (1997) A new translational regulator with homology to eukaryotic translation initiation factor 4G. EMBO J. 16:817825

144. Levy-Strumpf N, Deiss LP, Berissi H and Kimchi A (1997) DAP-5, a novel homolog of eukaryotic translation initiation factor $4 \mathrm{G}$ isolated as a putative modulator of gamma interferon-induced programmed cell death. Mol. Cell. Biol. 17: $1615-1625$

145. Yamanaka S, Poksay KS, Arnold KS and Innerarity TL (1997) A novel translational repressor mRNA is edited in livers containing tumors caused by the transgene expression of the ApoB-mRNA editing enzyme. Genes and Dev. 11: $321-333$

146. Methot N, Song MS and Sonenberg N (1996) A region rich in aspartic acid, arginine, tyrosine, and glycine (DRYG) mediates eukaryotic initiation factor 4B (elF4B) self-association and interaction with elF3. Mol. Cell. Biol. 16: 53285334

147. Méthot N, Pause A, Hershey JWB and Sonenberg N (1994) The translation initiation factor elF-4B contains an RNA-binding region that is distinct and independent from its ribonucleoprotein consensus sequence. Mol. Cell. Biol. 14: 2307-2316

148. Block KL, Vornlocher HP and Hershey JWB (1998) Characterization of cDNAs encoding the p44 and p35 subunits of human translation initiation factor elF3. J. Biol. Chem. 273: $31901-31908$

149. Lazaris-Karatzas A, Montine KS and Sonenberg N (1990) Malignant transformation by a eukaryotic initiation factor subunit that binds to mRNA $5^{\prime}$ cap. Nature 345: $544-547$

150. Fukuchi-Shimogori T, Ishii I, Kashiwagi K, Mashiba H, Ekimoto Hand Igarashi K (1997) Malignant transformation by overproduction of translation initiation factor elF4G. Cancer Res. 57: 5041-5044

151. Donzé O, Jagus R, Koromilas AE, Hershey JWB and Sonenberg N (1995) Abrogation of translation initiation factor elF-2 phosphorylation causes malignant transformation of NIH 3 T3 cells. EMBO J. 14: 3828-3834

152. Clemens MJ and Bommer UA (1999) Translational control: the cancer connection. Int. J. Biochem. Cell Biol. 31: 1-23

153. De Benedetti A and Harris AL (1999) elF4E expression in tumors: its possible role in progression of malignancies. Int. J. Biochem. Cell Biol. 31: 59-72

154. Koromilas AE, Lazaris-Karatzas A and Sonenberg N (1992) mRNAs containing extensive secondary structure in their $5^{\prime}$ non-coding region translate efficiently in cells overexpressing initiation factor elF-4E. EMBO J. 11: 4153-4158

155. De Benedetti A, Joshi-Barve S, Rinker-Schaeffer C and Rhoads RE (1991) Expression of antisense RNA against initiation factor elF-4E mRNA in HeLa cells results in lengthened cell division times, diminished translation rates, and reduced levels of both elF-4E and the 220 component of elF-4F. Mol. Cell. Biol. 11: $5435-5445$

156. Graff JR, Boghaert ER, De Benedetti A, Tudor DL, Zimmer CC, Chan SK and Zimmer SG (1995) Reduction of translation initiation factor 4E decreases the malignancy of ras-transformed cloned rat embryo fibroblasts. Int. J. Cancer 60: $255-263$

157. Li BDL, Liu L, Dawson M and De Benedetti A (1997) Overexpression of eukaryotic initiation factor 4E (elF4E) in breast carcinoma. Cancer 79: 2385 2390

158. Nathan CAO, Liu L, Li BD, Abreo FW, Nandy I and De Benedetti A (1997) Detection of the proto-oncogene elF4E in surgical margins may predict recurrence in head and neck cancer. Oncogene 15: 579-584

159. Nathan CA, Carter P, Liu L, Li BD, Abreo F, Tudor A, Zimmer SG and De Benedetti A (1997) Elevated expression of elT4E and FGF-2 isoforms during vascularization of breast carcinomas. Oncogene 15: 1087-1094

160. Brass N, Heckel D, Sahin U, Pfreundschuh M, Sybrecht GW and Meese E (1997) Translation initiation factor elF-4gamma is encoded by an amplified gene and induces an immune response in squamous cell lung carcinoma. Hum. Mol. Genet. 6: 33-39

161. Ohlmann T, Rau M, Morley SJ and Pain VM (1995) Proteolytic cleavage of initiation factor elF-4gamma in the reticulocyte lysate inhibits translation of capped mRNAs but enhances that of uncapped mRNAs. Nucleic Acids Res. 23: $334-340$

162. Yueh A and Schneider RJ (1996) Selective translation initiation by ribosome jumping in adenovirus-infected and heat-shocked cells. Genes Dev. 10: 15571567 
163. Stoneley M, Chappell SA, Jopling CL, Dickens M, MacFarlane M and Willis AE (2000) C-myc protein synthesis is initiated from the internal ribosome entry segment during apoptosis. Mol. Cell. Biol. 20: 1162-1169

164. Deveraux QL and Reed TC (1999) IAP family proteins - suppressors of apoptosis. Genes Dev. 13: 239-252

165. Jäättelä M (1999) Escaping cell death: Survival proteins in cancer. Exp. Cell Res. 248: $30-43$

166. Polunovsky VA, Wendt CH, Ingbar DH, Peterson MS and Bitterman PB (1994) Induction of endothelial cell apoptosis by TNF alpha: modulation by inhibitors of protein synthesis. Exp. Cell Res. 214: 584-594

167. O'Reilly LA and Strasser A (1999) Apoptosis and autoimmune disease. Inflamm. Res. 48: 5-21

168. Rosen A and Casciola-Rosen L (1999) Autoantigens as substrates for apoptotic proteases: implications for the pathogenesis of systemic autoimmune disease. Cell Death Differ. 6: 6-12
169. Svitkin YV, Ovchinnikov LP, Dreyfuss G and Sonenberg N (1996) General RNA binding proteins render translation cap dependent. EMBO J. 15: 7147-7155

170. James MC, Jeffrey IW, Pruijn GJM, Thijssen JPH and Clemens MJ (1999) Translational control by the La antigen: Structure requirements for rescue of the double-stranded RNA-mediated inhibition of protein synthesis. Eur. J. Biochem. 266: 151-162

171. Rutjes SA, Utz PJ, van der Heijden A, Broekhuis C, van Venrooij WJ and Pruijn GJM (1999) The La (SS-B) autoantigen, a key protein in RNA biogenesis, is dephosphorylated and cleaved early during apoptosis. Cell Death Differ. 6: 976-986

172. Casciola-Rosen L, Andrade F, Ulanet D, Wong WB and Rosen A (1999) Cleavage by granzyme $B$ is strongly predictive of autoantigen status: Implications for initiation of autoimmunity. J. Exp. Med. 190: 815-825 